University of Nebraska - Lincoln

DigitalCommons@University of Nebraska - Lincoln

Faculty Publications, Department of Psychology

Psychology, Department of

August 1999

\title{
Double Discounting: The Effects of Comparative Negligence on Mock Juror Decision Making
}

Douglas J. Zickafoosel

Louisiana State University

Brian H. Bornstein

University of Nebraska-Lincoln, bbornstein2@unl.edu

Follow this and additional works at: https://digitalcommons.unl.edu/psychfacpub

Part of the Psychiatry and Psychology Commons

Zickafoosel, Douglas J. and Bornstein, Brian H., "Double Discounting: The Effects of Comparative Negligence on Mock Juror Decision Making" (1999). Faculty Publications, Department of Psychology. 171.

https://digitalcommons.unl.edu/psychfacpub/171

This Article is brought to you for free and open access by the Psychology, Department of at DigitalCommons@University of Nebraska - Lincoln. It has been accepted for inclusion in Faculty Publications, Department of Psychology by an authorized administrator of DigitalCommons@University of Nebraska - Lincoln. 


\title{
Double Discounting: The Effects of Comparative Negligence on Mock Juror Decision Making
}

\author{
Douglas J. Zickafoosel and Brian H. Bornstein \\ Department of Psychology, Louisiana State University, Baton Rouge
}

Two experiments were conducted to ascertain the effects of comparative negligence on damage awards. Participants awarded damages for a mock medical malpractice case in which the level of the plaintiff's negligence was varied. Both experiments showed that damage awards were doubly discounted for partially negligent plaintiffs. Experiment 1 also found that the responses of college students did not differ from those of people who had been called for jury duty. Experiment 2 examined four components of the damage award and showed that the reduction due to the level of the plaintiff's negligence occurred only in damages for bodily harm. Implications for the judicial system are discussed.

\section{INTRODUCTION}

Jurors often report experiencing difficulty in determining the amount of damages to award in civil trials. Reasons for this difficulty include the complexity of placing a dollar amount on the plaintiff's injuries and the fact that little or no guidance is given in how to award damages (Boswell \& Buda, 1996; Broeder, 1958; Goodman, Greene, \& Loftus, 1989; Greene \& Bornstein, in press; Wissler, Evans, Hart, Morry, \& Saks, 1997). When comparative negligence is applied to a case, jurors may face an even more difficult task. Under comparative negligence laws, plaintiffs may be found to be partly responsible for their own injuries. This means that the jury must not merely determine liability beyond a certain threshold (e.g., preponderance), but must also decide how responsible each party is. The jury then determines a damage award that is supposed to be independent of the liability issue, knowing that this award will be reduced by the court in accordance with the degree of negligence attributed to the plaintiff. 


\section{Comparative Negligence}

Most of the states that have comparative negligence standards adopted them in the early 1970s (Shanley, 1985). These standards are now applicable in almost every state, as well as in some federal statutes (Schwartz, 1994). ${ }^{1}$ There are two main types of comparative negligence: pure comparative negligence and modified comparative negligence. Under the pure form (used by 13 states), a plaintiff may recover damages even if his or her negligence is greater than that of the defendant. Under modified comparative negligence (used by 33 states), the plaintiff may recover damages only if his or her negligence is less than $49 \%$ ("Wisconsin Rule") or less than or equal to $50 \%$ ("New Hampshire Rule") of that of the defendant. Regardless of whether pure or modified comparative negligence is used, the damage award is reduced by the amount of negligence attributed to the plaintiff (Schwartz, 1994).

Prior to changing to comparative negligence, the standard was (and still is in the four states that have not changed) contributory negligence. Under contributory negligence any negligence by the plaintiff would bar recovery of damages. By changing from a contributory to a comparative negligence standard, one would expect more decisions for the plaintiff, since it is easier to establish partial fault than complete fault. One would also expect smaller average awards, since any plaintiff negligence would reduce the award by the amount of the plaintiff's negligence. Indeed, a study done by a jury-verdicts reporting service of the first 1,076 jury trials under the comparative negligence law in Cook County, Illinois, found an increase in plaintiff victory rate from roughly $50 \%$ to $59 \%$, while the awards were reduced by an average of $43 \%$ (Shanley, 1985).

Additionally, Shanley (1985) compared jury verdicts for auto accident cases in San Francisco during the period just after the change to comparative negligence (1975-1980) to those during the period immediately before the change (1970-1974). As expected, the probability of the plaintiff's winning increased following the change to comparative negligence. Furthermore, the gross damage awards for partially negligent plaintiffs were found to be lower than for comparable nonnegligent plaintiffs. Since the gross awards were then reduced by the level of the plaintiff's negligence by the court, the final award would have been reduced twice, or doubly discounted. Hammitt, Carroll, and Relles (1985), in examining all the cases tried in Chicago and San Francisco from 1960 to 1979, as well as verdicts collected in a nationwide sample of auto insurance claims, also found evidence of this double discounting.

A limitation of these archival studies is that there may be a selection bias, such that cases involving comparative negligence claims may have different characteristics from cases not involving comparative negligence. Furthermore, there is a lack of control over extraneous variables, such as the size of the ad damnum (i.e., the amount requested by the plaintiff), which have been shown to affect damage awards in simulation studies (Chapman \& Bornstein, 1996; Hinsz \& Indahl, 1995; Raitz, Greene, Goodman \& Loftus, 1990; MacCoun, 1993).

${ }^{1}$ As of 1994, 46 states had adopted some form of comparative negligence. Alabama, Maryland, North Carolina, and Virginia are the 4 states that had not changed to a comparative negligence standard by 1994. 
Jury simulations are able to hold such extraneous variables constant, but little simulation work has been done which manipulates the degree of plaintiff negligence. Thomas and Parpal (1987), using college students as mock jurors, examined liability as a function of plaintiff and defendant fault. They gave each participant five fictitious case summaries in which they manipulated both the plaintiff's and the defendant's apparent fault. Participants first rated the responsibility of both the plaintiff and the defendant for the harm incurred by the plaintiff, then assessed liability against the defendant and awarded damages. They found that the rule "liability should be proportional to fault" was not an adequate description of the data. They did find, however, that apparent fault influenced attributions of responsibility, which then influenced the amount of damages awarded. Hence, they found at least an indirect relationship between the level of comparative negligence and the amount of the damage award, but the reductions in the amounts of the awards were not directly proportional to the plaintiff's level of negligence as determined by the participants.

Feigenson, Park, and Salovey (1997) manipulated the blameworthiness of the victim and the severity of the accident across four different case summaries. Participants estimated the fault for both the plaintiff and defendant, determined a gross damage award, and then determined an adjusted damage award that was discounted by the percentage of fault attributed to the plaintiff. They found that participants conflated the issues of liability and damage awards, as indicated by both liability and damage awards being affected by legally irrelevant issues (i.e., defendant's blameworthiness affected damage awards, and severity of the plaintiff's injury affected liability judgments). They also found a fairly consistent antiplaintiff bias exhibited by reductions in the gross damage awards of more blameworthy plaintiffs, leading to double discounting.

\section{Fusion and Double Discounting}

The above two studies provide initial experimental evidence for the double discounting of damage awards of partially negligent plaintiffs. Further, the results of these studies are consistent with claims that jurors "fuse" the issues of liability and damages (Bornstein, 1998; Greene, 1989; Horowitz \& Bordens, 1990; MacCoun, 1993). The question, then, is why do jurors fuse liability and damages? Research on the "hindsight bias" provides one possible explanation.

The hindsight bias may best be described as the "I knew it all along" phenomenon. Once the outcome of an event is known (e.g., baseball game, political election, medical procedure), people tend to overestimate the likelihood that they would have predicted that outcome a priori (Christensen-Szalanski \& Willham, 1991; Hawkins \& Hastie, 1990). In the laboratory, a typical study on the hindsight bias would involve informing some individuals of the outcome of a target event, while withholding that outcome information from others. All of the individuals would then be asked to estimate the probability of the outcome of the event as if they had not received any outcome information. The general finding is that individuals receiving the outcome information estimate the probability of its occurrence significantly higher than those not receiving the outcome information (Christensen-Szalanski \& Willham, 1991; Fischhoff, 1975; Hawkins \& Hastie, 1990). 
In a civil trial, particularly personal injury cases, jurors are exposed to outcome information. An injury has occurred to the plaintiff that has led to a lawsuit. While jurors are not asked to make a specific probability judgment of the occurrence of the injury had they not known the outcome, as would be the case in a typical hindsight study, they must decide on liability according to the preponderance of the evidence, which can be viewed as a type of probability judgment (Saks \& Kidd, 1980). Indeed, although a civil trial is not directly analogous to the typical hindsight bias study, other types of psychological phenomena may either share a paradigmatic form with the hindsight bias or involve similar underlying psychological mechanisms (Hawkins \& Hastie, 1990). In a civil trial, an example of such a phenomenon would be the misapplication of jury instructions (Hawkins \& Hastie, 1990).

One well-known misapplication of jury instructions involves the instruction to ignore inadmissible evidence. Thompson, Fong, and Rosenhan (1981) examined the impact of inadmissible evidence, which mock jurors were instructed to ignore, in a criminal trial. They found that mock jurors who received proacquittal inadmissible evidence were less likely to convict than when given proconviction inadmissible evidence or no inadmissible evidence. This misapplication of juror instructions is not limited to criminal trials. Casper, Benedict, and Perry (1989) examined the effect of the hindsight bias on mock jurors' damage awards in civil suits brought against police officers alleged to have engaged in illegal searches. They found that information about the outcome of the search (i.e., evidence of a crime was or was not found) affected mock jurors' determination of damages, even though the judge instructed them to ignore that information.

Both of the above studies illustrate that information presented to mock jurors can influence their decision making even when they are specifically instructed by the judge to ignore it. They are consistent with other research showing that jurors appear to "fuse" different types of judgments, in that information relevant to one judgment - such as damages - influences another judgment for which it is legally irrelevant, such as liability (Bornstein, 1998; Feigenson et al., 1997). Determining damages in a comparative negligence case may be likened to the studies above, in that jurors are instructed to ignore the amount of negligence attributed to the plaintiff when deciding the gross damage award; that is, participants are asked to determine the amount of damages that the plaintiff would have received if he or she was not at all responsible for his or her own injuries. However, once jurors are aware of any plaintiff contribution to the injuries, studies of the hindsight bias and the effect of inadmissible evidence suggest that this information will be incorporated into their decision-making processes.

\section{Experimental Overview}

The present research is an experimental attempt to explore the effects of outcome information, in the form of information about comparative negligence, on damage awards. Because the focus of the present experiments is on how mock jurors apply the instructions concerning comparative negligence in making damage awards, any type of case could have been used. We used a medical malpractice case because (1) much of the ongoing tort reform debate focuses on medical 
malpractice cases (Vidmar, 1995), (2) a change in recent years in the physicianpatient relationship allows for more patients to contribute to their own injuries (Murphy, 1991), and (3) there are limitations to the Thomas and Parpal (1987) and Feigenson et al. (1997) studies on comparative negligence.

Recently tort reform has been a popular issue, particularly regarding medical malpractice (Litan, 1993; Vidmar, 1995). Some of the issues of contention include capping damage awards, instituting bifurcated trials, and even replacing juries in medical malpractice cases with professional review boards (Daniels \& Martin, 1986; Greene, 1989; Vidmar, 1995). These reform efforts usually include claims that juries are overly generous to plaintiffs, thus showing an antidefendant bias. The present framework can address whether juries are overly generous to plaintiffs. A finding of double discounting would indicate that jurors are not overly generous to plaintiffs and, if anything, exhibit an antiplaintiff instead of an antidefendant bias.

A second reason for using a medical malpractice case is in response to a societal change in the physician-patient relationship such that patients are no longer assumed to be totally unaware of their health care needs (Murphy, 1991). This increase in control over the decision-making process has opened the door for patients to contribute negligence, and thus for comparative negligence to be used as a defense. In accordance with this development, the case summary used was taken from an actual case (Surgeon ruled liable for hair transplant, 1996) in which comparative negligence was used as a defense and the plaintiff was found to be $30 \%$ negligent.

Finally, Thomas and Parpal (1987) did not include a medical malpractice case in their study. While Feigenson et al. (1997) did include a medical malpractice case and failed to find differences between types of cases, the findings of both studies may be clouded because participants determined liability prior to awarding damages. Further, both studies manipulated the level of plaintiff negligence indirectly (i.e., through descriptions of the plaintiff's behavior). This does not allow for the comparison of awards between specific levels of plaintiff negligence. Our methodology explicitly manipulates the specific level of the plaintiff's negligence, allowing for more direct comparisons across various levels of plaintiff negligence.

Two experiments were conducted in which participants awarded compensation after reading a case summary in which the level of the plaintiff's negligence was varied. Three levels of plaintiff negligence were used: $0 \%, 20 \%$, and $40 \%$. Of main concern was to determine whether there would be a difference in damage awards between nonnegligent plaintiffs and partially negligent plaintiffs (i.e., $0 \%$ versus $20 \%$ and $40 \%$ ). While the law as written treats the determination of negligence and the awarding of damages as independent issues, the findings from both archival (Hammitt et al., 1985; Shanley, 1985) and experimental studies (Feigenson et al., 1997; Thomas \& Parpal, 1987) suggest that participants will not treat them independently, resulting in lower damage awards to partially negligent plaintiffs. A secondary issue concerning plaintiff negligence is whether the degree of partial negligence has an effect. This issue was addressed by comparing two levels of partially negligent plaintiffs (20\% vs. $40 \%)$.

In addition to the effects of comparative negligence, there has been interest in the strategies that jurors use in determining damages (e.g., Goodman et al., 1989; 
Greene, 1989; Raitz et al., 1990). An attempt to address this issue was made as well, particularly in Experiment 2.

\section{EXPERIMENT 1}

Participants were asked to determine damage awards for a medical malpractice case in which liability had already been established for both the defendant and the plaintiff. In a comparative negligence case jurors are instructed to ignore the plaintiff's negligence when determining damages. However, it has been shown that jurors are unable to ignore information they have been given, even when instructed to do so by the judge (Casper et al., 1989; Thompson et al., 1981). Further, it has been shown that jurors tend to fuse liability judgments and compensatory damage awards (Bornstein, 1998; Feigenson et al., 1997; Greene, 1989; Horowitz \& Bordens, 1990). These findings led to the prediction that participants would be unable to ignore the level of the plaintiff's negligence when determining the damage award, and would therefore award less to partially negligent plaintiffs.

In addition, some studies have shown that reductions in the damage awards were proportional to fault (Hammitt et al., 1985), while others have not (Thomas \& Parpal, 1987). This issue was addressed by comparing the $20 \%$ and $40 \%$ negligence conditions. Due to the conflicting findings cited above, no predictions were made concerning the effect of varying the level of partial plaintiff negligence.

\section{Method}

\section{Participants}

Participants were 82 introductory psychology students who received extra credit for their participation and 69 people who had been called for jury duty (hereafter referred to as "jurors") in either Baton Rouge or Gonzales, Louisiana, who volunteered to participate in the study. The demographic makeup was similar for both groups except for age ( $M d n \mathrm{~s}=19$ and 41 years, respectively). For jurors, 53\% were male and $87 \%$ were White; while for students, $41 \%$ were male and $80 \%$ were White.

\section{Materials and Design}

A $3 \times 2$ between-subjects design was used with three levels of plaintiff negligence $(0 \%, 20 \%$, and $40 \%)$ and two levels of participant status (students and jurors).

Each packet contained a summary of a medical malpractice case, the judge's instructions on how to determine damages, and a response sheet. ${ }^{2}$

Case Summary. The case summary was adapted from an actual medical malpractice case (Surgeon ruled liable for hair transplant, 1996). After undergoing a series of five surgeries for hair transplants, the plaintiff was still losing hair and was left with large scars around his face. This sent the plaintiff into a deep depression resulting in a failed suicide attempt. The plaintiff claimed that the physician minimized the risks of the extensive surgery, and he indicated that had he been aware that the surgery could

\footnotetext{
${ }^{2}$ A complete copy of the materials may be obtained from the authors.
} 
result in such large scars, he would never have undergone the procedure. The plaintiff sued his doctor for not making the risks clear concerning his hair transplant surgery and sought compensation for the scars from the surgery itself, injuries from the suicide attempt, lost wages from missed work, and medical costs. Based on pilot testing, the amount requested by the plaintiff was set at $\$ 50,000$.

The summary included information concerning the cost of the failed surgery $(\$ 15,000)$, the cost of additional medical expenses $(\$ 10,000)$, the plaintiff's yearly salary $(\$ 25,000)$, and the amount of time the plaintiff had missed from work (5 weeks). Yearly salary and time missed from work were both included to allow participants to compute lost earnings themselves.

The summary informed participants (1) that their jury had already found the defendant liable for medical malpractice, (2) that the plaintiff had contributed to his injuries (either $0 \%, 20 \%$, or $40 \%$ ) by not properly educating himself about the transplant surgery, and (3) that their only job was to determine how much compensation, if any, the plaintiff was to receive from the defendant. For the $0 \%$ plaintiff negligence condition participants were told that the defense claimed the plaintiff was partly responsible for the injuries, but the jury had disagreed and found the defendant to be completely responsible.

Judge's Instructions. The judge's instructions were taken from Louisiana jury instructions, Volume 11, Civil (Johnson, 1980). The instructions included a brief description of what constitutes negligence and how comparative negligence is determined. The section concerning comparative negligence indicated that "the plaintiff may be partially responsible for his own injuries," but that the jurors were to determine the gross amount of damages incurred by the plaintiff without regard to the plaintiff's degree of negligence. This amount should "fairly and adequately compensate the plaintiff for the damages he has already suffered, and that he will in all likelihood suffer in the future." They were told that this amount would then be reduced by the judge according to the level of negligence attributed to the plaintiff. The judge's instructions also included examples of what participants could award damages for (pain and suffering, medical expenses, lost wages, and bodily harm) and what they were not to consider in determining damages (punitive damages, court costs, lawyers' fees, and taxes on the amount awarded).

Dependent Variables. The response sheet asked for the total amount to be awarded to the plaintiff, how much participants agreed with the assigned plaintiff negligence (5-point scale, with 1 being not at all and 5 being completely), and how easy it was to determine the damages (5-point scale, with 1 being very hard and 5 being very easy).

Following the award, there was an open-ended question asking how the participant had determined the amount awarded.

\section{Procedure}

Participants were randomly assigned to negligence conditions and tested individually in groups of up to 25 . They were given the packets and told to imagine that they were on a real jury that must decide how much money, if any, to award to the plain- 
tiff in a medical malpractice case. Participants were told further that the case involved comparative negligence and were given an example of how the damage award is reduced by the judge. These instructions were both written for the participants and read to them by the experimenter. They then read the case summary and decided on the amount to be awarded. The total procedure took about $20 \mathrm{~min}$ to complete.

\section{Results}

Two participants' data were removed for failure to follow instructions, and 4 other participants were removed for making nonspecific awards (e.g., "the same," " $50-75 \mathrm{~K}$ "), leaving 145 participants for analysis. Because of the high variability in the data, the natural log of the damage award was used for analysis (Cather, Greene, \& Durham, 1996; Chapman \& Bornstein, 1996; Moller, 1996,1997; Shanley, 1985; Wissler et al., 1997). The damage awards (as well as agreement and ease at determining damages) were analyzed using $3 \times 2$ between-subjects ANOVAs with three levels of plaintiff negligence $(0 \%, 20 \%, 40 \%)$ and two levels of participant status (students vs. jurors). All tests were conducted with alpha set at .05.

\section{Damage Awards}

Figure 1 shows the mean damage award for each negligence condition. The main effect for negligence was significant, $F(2,139)=3.07, p<.05$. Planned contrasts showed that participants awarded more damages in the $0 \%$ condition $(M=\$ 54,103$, $S D=\$ 52,462)$ than in the $20 \%$ and $40 \%$ conditions combined $(M=\$ 38,273, S D=$ $\$ 18,968), t(142)=2.36, p=.02$, with no difference between the $20 \%(M=\$ 40,419$, $S D=\$ 19,146)$ and $40 \%(M=\$ 36,173, S D=\$ 18,754)$ conditions, $t(142)<1$. Neither the main effect for participant status nor, the participant status by negligence interaction was significant, $F(1,139)=2.76, p=.10$, and $F(2,139)<1$, respectively.

\section{Agreement with Negligence}

As with the damage awards, the main effect for plaintiff negligence was significant, $F(1,128)=3.85, p=.02$. Participants agreed with the two partial negligence conditions $(M=3.22, S D=1.27)$ more than the $0 \%$ condition $(M=2.55$, $S D=1.42), t(131)=2.77, p<.01$, with no difference between the two partial negligence conditions, $t<1(20 \%: M=3.33, S D=1.37 ; 40 \%: M=3.11, S D=1.17)$. Also, as with the damage awards, neither the main effect for participant status nor the negligence by participant status interaction was significant, $F \mathrm{~s}<1$.

\section{Ease of Determining Damages}

Neither participant status nor degree of negligence affected how easy participants found it to determine damages $\left(F_{\mathrm{S}}<2.20, p \mathrm{~s}>.14\right)$.

\section{Explanation of Damage Award}

Responses to this question were coded according to the strategy participants reported using to determine the damage award. Five categories were used: (1) picked 


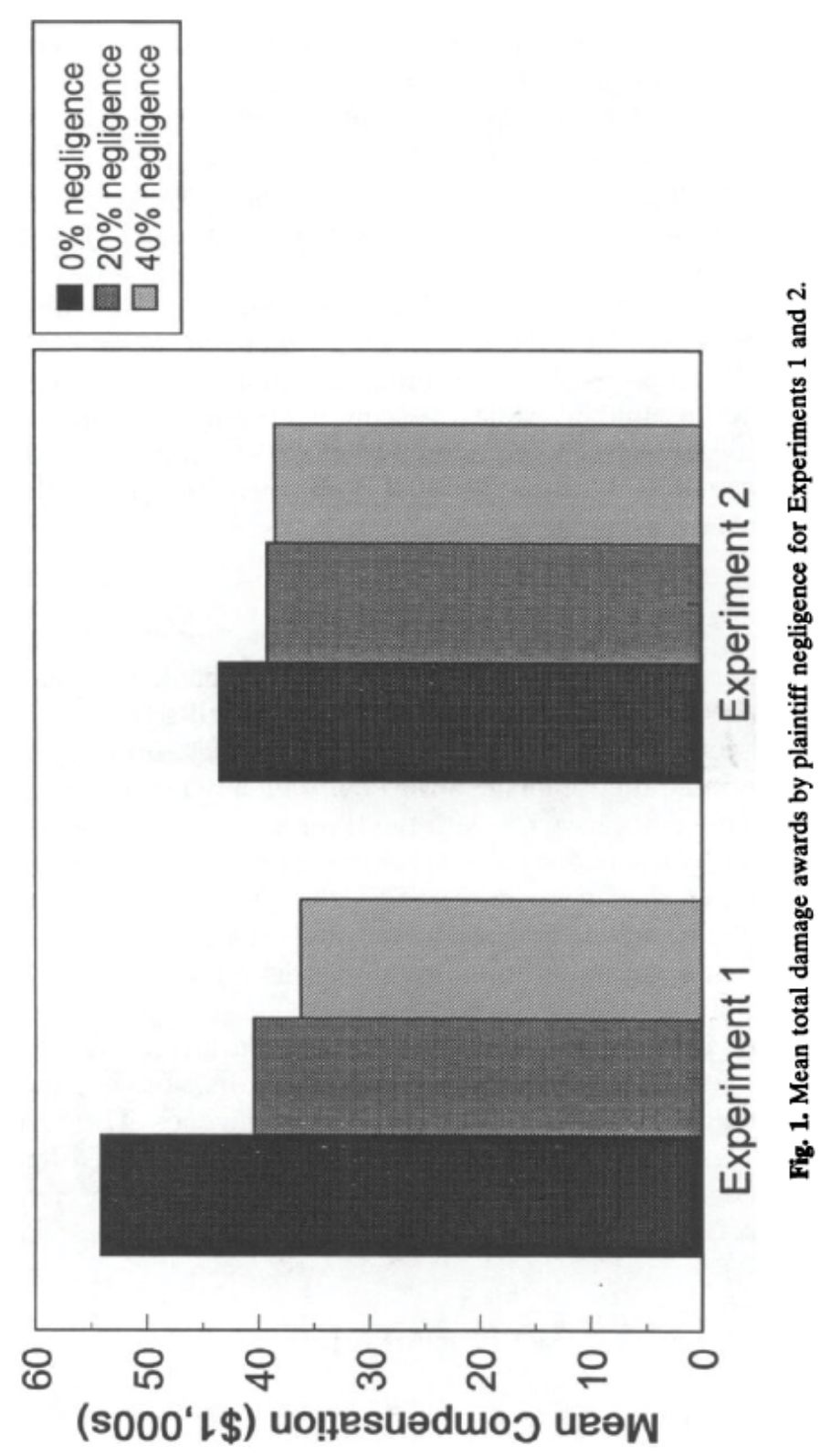


a fair amount without computation, (2) computed some number and left it at that, (3) computed a number and then adjusted it, (4) awarded the ad damnum, and (5) specifically reduced the amount by the level of plaintiff negligence. The first three categories were taken from those used by Goodman et al. (1989), while the fourth category was based on previous studies that found the ad damnum to be the modal amount awarded (Chapman \& Bornstein, 1996; Raitz et al., 1990). The final category was established as a manipulation check for the instructions (i.e., those falling into this category admittedly failed to follow the instructions). The categories were not mutually exclusive. Two raters independently scored these questions, with interrater agreement of $85 \%$. All disagreements were reconciled between the two raters.

Twenty-five percent of the participants awarded the ad damnum, which was the modal amount awarded. Furthermore, as in Goodman et al. (1989), the majority of participants $(62 \%)$ reported having computed a number in determining damages (50\% just computed a number, while $12 \%$ computed a number and then adjusted it). Finally, 14\% of the participants indicated that they considered the plaintiff's negligence in determining the award (all of these participants were in the two partial plaintiff negligence conditions).

\section{Discussion}

The main finding from Experiment 1 is that, as predicted, mock jurors returned lower total damage awards to partially negligent plaintiffs than to nonnegligent plaintiffs. This discounting occurred even though (1) mock jurors were specifically instructed to determine their damage award ignoring any plaintiff negligence, and (2) mock jurors tended not to agree with the level of responsibility assigned to the nonnegligent plaintiff. The implication is that jurors take into account liability issues (i.e., the plaintiff's level of negligence) and reduce the damage award when the plaintiff contributes to his own injuries. We suggest that this fusion of liability and damages, which ultimately results in doubly discounted damage awards, is a consequence of hindsight.

A second main finding from Experiment 1 is that the awards by college students did not differ significantly from the awards made by jurors, nor were the two groups affected differentially by the level of comparative negligence. This result supports other findings (e.g., Bornstein, 1999; Bornstein \& Rajki, 1994; Cutler, Dexter, \& Penrod, 1989) that the use of college students in psycholegal research is not in itself problematic.

\section{EXPERIMENT 2}

Since in Experiment 1 it was found that participants discounted the awards due to plaintiff negligence, Experiment 2 explored which components of the award mock jurors reduced. Although little or no instructions are given concerning how to determine the different types of damages, most states do provide some instruction about what jurors should consider when determining the damage award (Wissler, Kuehn, $\&$ Saks, 1998). While the specific components that are included, and how well each component is defined, vary across jurisdictions (Wissler et al., 1998), instructions 
generally include two types of compensatory damages: economic and noneconomic (Cather et al., 1996; Greene \& Bornstein, 1998; Wissler et al., 1997,1998).

Economic, or specific, damages refer to the financial costs, both past and future, actually incurred (or expected to be incurred) by the plaintiff as a result of the injury (Cather et al., 1996; Vidmar, 1995; Wissler et al., 1997). The two most commonly reported components of economic damages are medical expenses and lost wages (Cather et al., 1996; Vidmar, 1995; Wissler et al., 1997). Noneconomic damages refer to components in which the only basis for determining damages is subjective human judgment (Cather et al., 1996; Vidmar, 1995). Components of noneconomic damages fall under two broad categories: pain and suffering, and the physical injury suffered (or bodily harm). ${ }^{3}$

Both pain and suffering and bodily harm are rather ambiguous, and neither is usually specifically defined. The main difference between the two components appears to be that pain and suffering awards are to compensate more for mental and emotional consequences such as mental anguish, emotional distress, humiliation, or shock; while damages for bodily harm are to compensate for more visible or physical consequences of the injury, such as disability, the loss of use of a body part, or disfigurement (Wissler et al., 1998).

Without a clear basis for awarding damages, one would expect jurors' interpretations, and subsequently their awards, to vary greatly (Raitz et al., 1990; Wissler et al., 1997,1998). Further, because of this wide variation, ambiguous tasks would be more susceptible to subjective influences of which jurors are unaware. As indicated above, noneconomic damages are subjective in nature, and the definitions of their components are highly ambiguous, so one might expect that double discounting would occur more for noneconomic than for economic damages.

Hammitt et al. (1985), in seeking to explain why damage awards were lower for comparative negligence cases (before being reduced by the court), concluded that "the standard instructions for comparative negligence are clear as written so it is more likely that juries give lower estimates for pain and suffering, mental anguish, and other intangibles when the plaintiff is in part responsible for the injury" (p. 758). We therefore predicted that there would not be any differences due to the plaintiff's negligence for the two economic damages components (medical expenses and lost income), but that partially negligent plaintiffs would receive less compensation for the noneconomic components of pain and suffering and bodily harm.

This prediction was tested in Experiment 2 by having participants award damages using a special verdicts form that separated the damage award into four components (two economic and two noneconomic). Participants' explanations in Experiment 1 indicated that most determined an award for each suggested category (e.g., lost wages) and then added the components together. Nineteen states provide for the use of special verdict forms in their comparative negligence statutes (Schwartz, 1994). While these statutes typically only require the jury to return a verdict stating the percentage of negligence of each party and the total amount of damages recoverable had the plaintiff not been partly responsible for the injuries

${ }^{3}$ A third category, loss of enjoyment of life, could also have been included. However, since it is usually included as a subgroup of pain and suffering, we will not treat it separately here. 
(Schwartz, 1994), some tort reform statutes (e.g., Florida and New York) also require the total damage award to be separated into economic and noneconomic damages (Schwartz, 1994).

Experiment 2 also attempted to explore experimentally the finding from Experiment 1 that most participants did some sort of computation to arrive at an award. Participants were forced either to determine the total damage award first, then divide this amount into the individual components (total first), or to determine amounts for the individual components before arriving at the total damage award (components first). The "components first" condition was designed to force participants to do some sort of computation in arriving at the total award. The order manipulation also allows for a comparison of different formats of special verdict forms.

\section{Method}

\section{Participants}

As Experiment 1 failed to find any difference in damage awards between college students and jurors, only college students participated in Experiment 2. Of 179 participants, 3 were dropped for failing to follow directions, resulting in 176 participants for analysis.

The same demographic information was collected as in Experiment 1. Twenty-five percent of participants were male and $78 \%$ were White, with a median age of 20 years.

\section{Materials and Design}

A $3 \times 2$ between-subjects design was used, with the same three levels of plaintiff negligence as in Experiment $1(0 \%, 20 \%, 40 \%)$, and two levels of order of response (total first or components first). The same materials were used as in Experiment 1, with the slight modification that a second response sheet was added. For the total first condition, the first response sheet remained the same as in Experiment 1, while the second response sheet contained a list of categories to consider in determining the award. These were (1) the physical injury suffered (i.e., bodily harm), (2) pain and suffering, both physical and emotional, (3) lost earnings, and (4) medical expenses. Participants only went to the second response sheet after they had completed the first response sheet. For the components first condition, the order of the response sheets was reversed. All participants were then asked how they had determined damages.

\section{Procedure}

The procedure was the same as in Experiment 1, with the added verbal instruction not to go to the next page until having completed each page. This instruction ensured that participants were forced to commit to an amount for the appropriate method (total first or components first) before determining the other types of awards. 


\section{Results}

As in Experiment 1, the natural log of the total damage award, agreement with plaintiff negligence, and ease of determining damages were analyzed in $3 \times$ 2 ANOVAs, with plaintiff negligence and order of response as between-subjects factors. In addition, the natural log of each of the four components was analyzed using a MANOVA with negligence and order as between-subjects factors.

\section{Total Damage Awards}

Supporting the findings from Experiment 1, the effect of plaintiff negligence was marginally significant, $F(2,164)=2.67, p=.07$ (see Fig. 1). Planned comparisons replicated Experiment 1, indicating that participants awarded significantly more for the $0 \%$ plaintiff negligence condition $(M=\$ 43,503, S D=\$ 12,069)$ than for the two partial plaintiff negligence conditions $(M=\$ 38,818, S D=\$ 12,954)$, $t(167)=2.29, p=.02$, with no difference between the $20 \%(M=\$ 39,213, S D=$ $\$ 12,521)$ and $40 \%(M=\$ 38,403, S D=\$ 13,502)$ plaintiff negligence conditions, $t(167)<1$. Neither the main effect for order of response nor the negligence by order interaction was significant, $F_{\mathbf{s}}<1$.

\section{Agreement with Negligence}

Supporting the findings from Experiment 1, the effect of plaintiff negligence was marginally significant, $F(2,160)=2.56, p=.08$. The planned comparisons indicated that participants in the partial plaintiff negligence conditions $(M=3.39$, $S D=0.98)$ agreed with the negligence assigned significantly more than those in the $0 \%$ plaintiff negligence condition $(M=3.00, S D=1.36), t(163)=2.11, p<$ .05 , with no significant difference between the $20 \%(M=3.28, S D=1.05)$ and $40 \%(M=3.50, S D=0.91)$ plaintiff negligence conditions, $t(163)=1.03, p>.3$. Neither the main effect for order of response nor the negligence by order interaction was significant, $F \mathrm{~s}<1.69, p \mathrm{~s}>.20$.

\section{Ease of Determining Damages}

As in Experiment 1, neither the main effect for plaintiff negligence nor the negligence by order interaction was significant for the ease of determining damages, $F_{\mathrm{S}}<1$. However, the main effect for order of response was significant, $F(1,160)=$ $3.76, p=.05$, with participants finding it easier to determine the total award first ( $M$ $=3.20, S D=1.04)$ than to determine the components first $(M=2.86, S D=1.17)$.

\section{Components of Damage Awards}

The largest awards were for medical expenses $(M=\$ 16,773, S D=\$ 8,282)$, followed by bodily harm $(M=\$ 10,075, S D=\$ 7,079)$, pain and suffering $(M=$ $\$ 9,279, S D=\$ 6,847)$, and then lost wages $(M=\$ 4,402, S D=\$ 3,822)$. Because the components were all significantly intercorrelated, a multivariate analysis was con- 
ducted with level of plaintiff negligence and order of response as between-subjects factors. Using Wilks' lambda, the multivariate test was significant for negligence, $F(8)=2.27, p=.02$, but not for order or the negligence by order interaction, $F_{\mathrm{S}}<1$. using the univariate tests, negligence had a significant effect only on the award for bodily harm, $F(2,140)=3.11, p<.05$. The same planned comparisons were carried out as for the total award and showed that participants awarded less to partially negligent plaintiffs $(M=\$ 9,382, S D=\$ 6,954)$ than to nonnegligent plaintiffs $(M=$ $\$ 11,473, S D=\$ 7,184), t(155)=2.35, p<.05$, with no difference between the two partial negligence conditions $(20 \%: M=\$ 10,184, S D=\$ 7,660 ; 40 \%: M=\$ 8,535$, $S D=\$ 6,079), t(155)=1.46, p=.15$. No other main effects or interactions were significant for any of the other components, $F \mathrm{~s}<2.19, p \mathrm{~s}>.10$.

\section{Explanation of Damage Awards}

The open-ended question was scored the same as in Experiment 1, with interrater agreement of $87 \%$. Twenty-four percent of participants awarded the ad damnum, which was the modal amount awarded. Again, the majority of participants $(78 \%)$ reported computing a number in determining damages (66\% just computed a number, and $12 \%$ computed a number and then adjusted it). Finally, 11\% of the participants specifically indicated that they considered the plaintiff's negligence in determining the damage award (all of these participants were in the two partial plaintiff negligence conditions). These figures are similar to those of Experiment 1.

\section{Discussion}

The main result of Experiment 2 was the replication of the double discounting of partially negligent plaintiffs' total damage award. Also, as in Experiment 1 , no difference was found between the $20 \%$ and $40 \%$ plaintiff negligence conditions, indicating that the degree of double discounting was not dependent on the specific level of the plaintiff's partial negligence.

The second main finding is that the reductions in the total damage awards due to plaintiff negligence reflected reductions only in the damage awards for the plaintiff's bodily harm. This finding partially supports the claim by Hammitt et al. (1985) that adjustments by jurors would be made in the less tangible components of the award. We suggest that the reductions were not merely due to the absence of a specific anchor for bodily harm, as the awards for pain and suffering, which also did not have a specific anchor, were not reduced. Wissler et al. (1997) also failed to find differences in damage awards for pain and suffering due to the level of plaintiff negligence. However, their pain and suffering award included consideration of bodily harm. Thus, our results are neither clearly supportive nor contrary to their findings.

The third main finding is that most participants computed damages rather than just picked a fair amount. The vast majority of participants, in both the total-first and the components-first conditions, reported having determined amounts for the various components prior to arriving at a total amount. This lack of a difference in award amounts due to the order of determining the damage awards suggests that imposing a strategy upon the participants (i.e., award- 
ing component amounts first) is consistent with the strategy that they developed and used on their own (i.e., in the total-first condition). Thus, while there are other ways to calculate damages than simply adding up the specified components, the current findings suggest that most participants computed damages by considering and then summing the discrete components. Additional evidence for participants doing some sort of computation emerges from the observation that many component awards were amounts that could be easily calculated from the information provided in the case summary.

Finally, participants perceived the task of determining damages as easier in the total-first condition than in the components-first condition, suggesting that they preferred their naive computational strategies to the formal strategy imposed by the requirement to award components first.

\section{GENERAL DISCUSSION}

The main finding from both experiments is that participants returned lower damage awards for partially negligent plaintiffs than for nonnegligent plaintiffs. Because these damage awards are then reduced by the court in accordance with the level of the plaintiff's negligence, the final award received by the plaintiff would be reduced twice, or doubly discounted. This finding of double discounting is consistent with both archival (Hammitt et al., 1985; Shanley, 1985) and experimental (Feigenson et al., 1997; Thomas \& Parpal, 1987) studies that have found lower gross awards for partially negligent plaintiffs. A second major finding was that the reduction in damage awards for partially negligent plaintiffs was reflected only in the amount awarded for bodily harm, lending partial support to the claim by Hammitt et al. (1985) that reductions would occur in damages awarded for relatively less tangible components.

Another main finding from Experiment 1 was the failure to find differences in the damage awards between college students and people who had been called for jury duty. This finding supports previous research which has generally failed to find differences between participant samples in both criminal (e.g., Cutler et al., 1989; MacCoun \& Kerr, 1988) and civil (e.g., Bornstein \& Rajki, 1994; Casper et al., 1989) cases. While this finding is not new, it does provide additional evidence from civil cases, which to a large extent has been lacking (Bornstein, 1999).

The final finding of importance concerns the process by which participants determined damage awards. Critics of juries claim damage awards are determined arbitrarily and/or based on emotion (see Litan, 1993, and Vidmar, 1995, for reviews). However, the present experiments, as well as others (Cather et al., 1996; Goodman et al., 1989; Greene, 1989; Raitz et al., 1990), indicate that most jurors performed computations in order to determine their awards, even when instructions encouraged them to do it holistically (i.e., the total-first condition in Experiment 2).

\section{Discounting, Fusion, and Hindsight}

Jurors in a comparative negligence case are faced with an extremely difficult task. Not only must they decide if the defendant was negligent, but they must also 
decide how much, if any, the plaintiff contributed to his or her own injuries. Then, if the level of the plaintiff's negligence allows for recovery, the jurors must determine a damage award that compensates fairly, based on instructions that provide little guidance (Wissler et al., 1998). Subsequently, jurors are required to consider a great deal of information concerning events with which they have little or no expertise. Because of the amount and complexity of this information, jurors are likely to rely on cognitive heuristics when reaching their decisions (Arkes, 1989; Chapman \& Bornstein, 1996; Saks \& Kidd, 1980). A common consequence of using heuristics is that the decisions are subject to systematic biases (Kahneman \& Tversky, 1974).

One such bias that could be used as a framework to explain why damage awards to partially negligent plaintiffs are reduced is hindsight (Christensen-Szalanski \& Willham, 1991; Fischhoff, 1975; Hawkins \& Hastie, 1990). According to this reasoning, once participants knew the outcome information-that is, that the plaintiff was partially negligent-they were unable to ignore that information in determining the damage award, even when instructed to do so by the judge. This inability to ignore information about partial negligence led them to fuse information about liability with their judgment about damages.

The trial situation may be especially susceptible to hindsight effects because of the difficulty and unfamiliarity of the tasks that jurors are expected to perform (i.e., determining liability and awarding damages). The effect size of the hindsight bias has been shown to be larger, the less familiar one is with the task (Christensen-Szalanski \& Willham, 1991; Hawkins \& Hastie, 1990). Hawkins and Hastie (1990) included situations involving the misapplication of jury instructions in their review of the hindsight bias, stating that such situations involve similar underlying psychological mechanisms.

One condition of the hindsight bias is a denial that the outcome information influenced one's judgment (Hawkins \& Hastie, 1990). Our data are consistent with this condition, in that only a small proportion of participants (14\% in Experiment 1 and $11 \%$ in Experiment 2) reported having been influenced by the level of the plaintiff's negligence when they determined the award. It has been argued that people, including judges (Ebbesen \& Konecni, 1975), may not be able to report accurately the factors that influence their decision making (Nisbett \& Wilson, 1977). Indeed, evidence that a much larger percentage of participants did not ignore the plaintiff's negligence comes from the observation that those who did not acknowledge its influence discounted their awards just as much as those who did. This finding suggests that although the majority of participants were influenced by the plaintiff's degree of negligence, they were unaware of it. Further research is needed that includes a direct measure of comprehension of the judge's instructions and focuses on the intentionality of discounting.

\section{Policy Implications}

The finding that mock jurors discount plaintiffs' gross awards according to their degree of negligence is consistent with previous research showing that jurors tend to fuse liability judgments and damage awards (Bornstein, 1998; Feigenson 
et al., 1997; MacCoun, 1993) and, in general, have a hard time applying legal instructions as they are intended (e.g., Thompson et al., 1981; Wissler et al., 1998). While some may claim that this discounting is acceptable because juries are supposed to reflect the consciousness of society and inject common sense into the legal process (Finkel, 1995), others may find it to be excessive.

Tort reform proponents have often claimed that juries are irrational, gullible, out of control, and affected too much by sympathy (for reviews, see Litan, 1993, and Vidmar, 1995). Thus they have proposed a number of reforms either to remove the jury from the decision-making process or at least to restrict their options. These reforms include the use of special verdict forms, capping damage awards, instituting bifurcated trials, and even replacing juries in medical malpractice cases with professional review boards (Daniels \& Martin, 1986; Greene, 1989; MacCoun, 1993; Vidmar, 1995; Wiggins \& Breckler, 1990).

However, in opposition to these claims, Vidmar (1995) found little evidence supporting the contention that jurors are biased against malpractice defendants. The present finding - that double discounting occurs in malpractice cases involving comparative negligence - supports Vidmar's conclusions, as double discounting can be construed as an antiplaintiff, not an antidefendant, effect (Feigenson et al., 1997).

The methodology employed in the current studies differs from previous studies on comparative negligence (Feigenson et al., 1997; Thomas \& Parpal, 1987) in that participants only determined damages. Not only does this procedure allow for the direct manipulation of the specific amount of negligence attributed to the plaintiff, it also provides a framework for examining the effectiveness of bifurcated trials. In a bifurcated trial, the jury initially considers only liability; then, if liability has been established, a second phase occurs in which a jury (either the same or a different one) is presented with information relevant only to damages (Horowitz \& Bordens, 1990). It is likely that determining both liability and damages would make the plaintiff's level of negligence more salient, thereby resulting in even greater discounting of the awards than when jurors award damages only. Although such a prediction is speculative, our findings suggest that bifurcation would not eliminate the double discounting of damage awards for partially negligent plaintiffs unless the second phase were completed by a new jury that was blindfolded to the plaintiff's liability. Blindfolding the jury to some issue is not uncommon (Diamond \& Casper, 1992), and it is sometimes used concerning the maximum level of plaintiff negligence that still allows for recovery (Schwartz, 1994).

Another reform that has been suggested is the use of special verdicts requiring the jury to respond to each contested issue (Vidmar, 1995; Wiggins \& Breckler, 1990). These special verdicts often require the jury to spell out the amounts awarded for the various types of economic and noneconomic damages. The use of special verdicts can aid in the judicial review of a case (MacCoun, 1993). By separating each damage issue, the judge can determine its appropriateness much more easily than if a general verdict is used. For example, if some type of damage award has been capped (e.g., pain and suffering), a special verdict enables the judge to determine easily if the jury awarded more than the cap allows. Such judgments are difficult, if not impossible, to make if only a general verdict is used. Al- 
though we did not directly compare awards made using a special verdict form to those using a general verdict form, the results of Experiment 2 can be used to address the format of special verdict forms. We failed to find differences in the damage awards due to the order in which damages were determined (total or components first), but participants reported finding it easier to determine damages in the total-first condition. Thus, providing jurors with a special verdict form requesting a total damage award prior to one for each component will be easier on the jurors without affecting the amount of damages awarded.

\section{Limitations and Future Directions}

A limitation of the current studies is that participants did not deliberate. However, since the same results concerning double discounting have also been found in archival studies (e.g., Shanley, 1985), it seems unlikely that deliberation would produce different results from those obtained from individuals. On the other hand, Guinther (1988) found that during deliberations, damage awards may become a bartering tool that allows a compromise between the majority and minority views. Thus, it is possible that during deliberations in a comparative negligence case, the level of the plaintiffs negligence could be used as a reason to raise or lower the damage award in order to get agreement by the jurors. Jurors might also trade off the percentage of negligence assessed for the amount awarded. Future studies involving deliberation are needed in order to solidify the generality of these effects.

Future studies are also needed that examine a wider range of plaintiff negligence levels. Although we found that the specific level of plaintiff negligence did not differentially affect the damage awards, our levels of plaintiff negligence $(20 \%$ vs. $40 \%)$ may not have been sensitive enough to produce a difference. Furthermore, because participants were informed of the plaintiff's level of responsibility rather than determining it for themselves, the specific level of the plaintiff's negligence given may not have been salient enough. As such, jurors may have treated that information in more of an all-or-none manner; that is, they were more concerned with whether the plaintiff contributed to his injuries at all than the exact amount contributed. Future studies examining plaintiff negligence levels should include conditions of slight plaintiff negligence (e.g., 5\% or less), as well as when the plaintiff's negligence is greater than that of the defendant.

Finally, because of the costs associated with implementing bifurcated trials for comparative negligence cases, research on ways to reduce double discounting would be beneficial. The hindsight bias has been resistant to attempts to eliminate it (Fischhoff, 1975; Hawkins \& Hastie, 1990), including instructing jurors to ignore some information (Casper et al., 1989; Thompson et al., 1981). However, strong countervailing instructions indicating that the outcome information was mistaken have been shown to eliminate the effects of hindsight for retrospective confidence ratings concerning almanac questions (Hasher, Attig, \& Alba, 1981). While this solution would not be feasible in a trial situation, there has been some evidence that instructions to reconsider the nonreported outcomes can reduce the hindsight effect (Slovic \& Fischhoff, 1977). This finding could be used to develop more explicit instructions concerning the role of hindsight in jurors' decision making. 


\section{ACKNOWLEDGMENTS}

This research was conducted by the first author in partial fulfillment of the requirements for a master's degree under supervision of the second author. We extend our gratitude to the judges and the juror services personnel at both the Baton Rouge and Gonzales courthouses for allowing us to recruit participants at each place. We also thank Sid O'Bryant for his help in collecting the data. The authors are grateful for the thoughtful comments and suggestions of Roselle Wissler.

\section{REFERENCES}

Arkes, H. R. (1989). Principles in judgment/decision making research pertinent to legal proceedings. Behavioral Sciences and the Law, 7, 429-456.

Bornstein, B. H. (1999). The ecological validity of jury simulations: Is the jury still out? Law and Human Behavior, 23, 75-91.

Bornstein, B. H. (1998). From compassion to compensation: The effect of injury severity on mock jurors' liability judgments. Journal of Applied Social Psychology, 28, 1477-1502.

Bornstein, B. H., \& Rajki, M. (1994). Extra-legal factors and product liability: The influence of mock jurors' demographic characteristics and intuitions about the cause of an injury. Behavioral Sciences and the Law, 12, $127-147$.

Boswell, L. (Producer) \& Buda, E. (Editor). (1996, June 19). The price of pain. Dateline NBC [Television Program]. New York: National Broadcasting Company.

Broeder, D. W. (1958). The University of Chicago jury project. Nebraska Law Review, 38, 744-761.

Casper, J. D., Benedict, K., \& Perry, J. L. (1989). Juror decision making, attitudes, and the hindsight bias. Law and Human Behavior, 13, 291-310.

Cather, C., Greene, E., \& Durham, R. (1996). Plaintiff injury and defendant reprehensibility: Implications for compensatory and punitive damage awards. Law and Human Behavior, 20, 189-205.

Chapman, G. B., \& Bornstein, B. H. (1996). The more you ask for, the more you get: Anchoring in personal injury verdicts. Applied Cognitive Psychology, 10, 519-540.

Christensen-Szalanski, J. J. J., \& Willham, C. F. (1991). The hindsight bias: A meta-analysis. Organizational Behavior and Human Decision Processes, 48, 147-168.

Cutler, B. L., Dexter, H. R., \& Penrod, S. D. (1989). Expert testimony and jury decision making: An empirical analysis. Behavioral Sciences and the Law, 7, 215-225.

Daniels, S., \& Martin, J. (1986). Jury verdicts and the "crisis" in civil justice. Justice System Journal, 11, 321-348.

Diamond, S. S., \& Casper, J. D. (1992). Blindfolding the jury to verdict consequences: Damages, experts, and the civil jury. Law and Society Review, 26, 513-563.

Ebbesen, E. B., \& Konecni, V. J. (1975). Decision making and information integration in the courts: The setting of bail. Journal of Personality and Social Psychology, 32, 805-821.

Feigenson, N., Park, J., \& Salovey, P. (1997). Effect of blameworthiness and outcome severity on attributions of responsibility and damage awards in comparative negligence cases. Law and Human Behavior, 21, 597-617.

Finkel, N. J. (1995). Commonsense justice: Jurors' notions of the law. Cambridge, MA: Harvard University Press.

Fischhoff, B. (1975). Hindsight $\neq$ Foresight: The effect of outcome knowledge on judgment under uncertainty. Journal of Experimental Psychology: Human Perception and Performance, 1, 288-299.

Goodman, J., Greene, E., \& Loftus, E. F. (1989). Runaway verdicts or reasoned determinations: Mock juror strategies in awarding damages. Jurimetrics Journal, 29, 285-309.

Greene, E. (1989). On juries and damage awards: The process of decision-making. Law and Contemporary Problems, 52, 225-246.

Greene, E., \& Bornstein, B. H. (in press). Precious little guidance: Jury instructions on damage awards. Psychology, Public Policy, and Law.

Guinther, J. (1988). The jury in America. New York: Facts on File.

Hammitt, J. K., Carroll, S. J., \& Relles, D. A. (1985). Tort standards and jury decisions. Journal of Legal Studies, 14, 751-762. 
Hasher, L., Attig, M. S., \& Alba, J. W. (1981). I knew it all along: Or, did I? Journal of Verbal Learning and Verbal Behavior, 20, 86-96.

Hawkins, S. A., \& Hastie, R. (1990). Hindsight: Biased judgments of past events after the outcomes are known. Psychological Bulletin, 107, 331-327.

Hinsz, V. B., \& Indahl, K. E. (1995). Assimilation to anchors for damage awards in a mock civil trial. Journal of Applied Social Psychology, 25, 991-1026.

Horowitz, I. A., \& Bordens, K. S. (1990). An experimental investigation of procedural issues in complex tort trials. Law and Human Behavior, 14, 269-285.

Johnson, H. A. (1980). Louisiana jury instructions, Volume 11, Civil. Baton Rouge, LA: Paul M. Herbert Law Center Publications Institute.

Kahneman, D., \& Tversky, A. (1974). Judgment under uncertainty: Heuristics and biases. Science, 185, 1124-1131.

Litan, R. E. (1993). Verdict: Assessing the civil jury system. Washington, DC: Brookings Institution.

MacCoun, R. J. (1993). Inside the black box: What empirical research tells us about decisionmaking by civil juries. In R. E. Litan (Ed.), Verdict: Assessing the civil jury system (pp. 137-180). Washington, DC: Brookings Institution.

MacCoun, R. J., \& Kerr, N. L. (1988). Asymmetric influence in mock jury deliberation: Jurors' bias for leniency. Journal of Personality and Social Psychology, 54, 21-33.

Moller, E. (1996). Trends in civil jury verdicts since 1985. Santa Monica, CA: Rand.

Moller, E. (1997). Explaining variation in personal injury jury awards. Santa Monica, CA: Rand.

Murphy, S. W. (1991). Contributory negligence in medical malpractice: Are the standards changing to reflect society's growing health care consumerism? University of Dayton Law Review, 17, 151-179.

Nisbett, R. E., \& Wilson, T. D. (1977). Telling more than we can know: Verbal reports on mental processes. Psychological Review, 84, 231-259.

Raitz, A., Greene, E., Goodman, J., \& Loftus, E. F. (1990). Determining damages: The influence of expert testimony on jurors' decision making. Law and Human Behavior, 14, 385-395.

Saks, M. J. (1992). Do we really know anything about the behavior of the tort litigation system - and why not? University of Pennsylvania Law Review, 140, 1147-1292.

Saks, M. J., \& Kidd, R. F. (1980). Human information processing and adjudication: Trial by heuristics. Law and Society Review, 15, 123-160.

Schwartz, V. E., (1994). Comparative negligence (3rd ed.). Indianapolis: Allen Smith.

Shanley, M. G. (1985). Comparative negligence and jury behavior. Santa Monica, CA: Rand.

Slovic, P., \& Fischhoff, B. (1977). On the psychology of experimental surprises. Journal of Experimental Psychology: Human Perception and Performance, 3, 544-551.

Surgeon ruled liable for hair transplant. (1996, September 19). The Wapakoneta Daily News, p. A11.

Thomas, E. A. C., \& Parpal, M. (1987). Liability as a function of plaintiff and defendant fault. Journal of Personality and Social Psychology, 53, 843-857.

Thompson, W. C., Fong, G. T., \& Rosenhan, D. L. (1981). Inadmissible evidence and juror verdicts. Journal of Personality and Social Psychology, 40, 453-463.

Vidmar, N. (1995). Medical malpractice and the American jury. Ann Arbor, MI: University of Michigan Press.

Wiggins, E. C., \& Breckler, S. J. (1990). Special verdicts as guides to jury decision making. Law and Psychology Review, 14, 1-41.

Wissler, R. L., Evans, D. L., Hart, A. J., Morry, M. M., \& Saks, M. J. (1997). Explaining "pain and suffering" awards: The role of injury characteristics and fault attributions. Law and Human Behavior, 21, 181-207.

Wissler, R. L., Kuehn, P., \& Saks, M. J. (1998). Instructing jurors on general damages in personal injury cases: Problems and possibilities. Manuscript submitted for publication. 